University of Nebraska - Lincoln

DigitalCommons@University of Nebraska - Lincoln

\title{
Oil productivity and composition of sunflower as a function of hybrid and planting date
}

\author{
Valtcho D. Zheljazkov \\ Mississippi State University, vjeliazk@uwyo.edu \\ Brady A. Vick \\ USDA-ARS \\ Brian S. Baldwin \\ Mississippi State University, bsb2@msstate.edu \\ Normie Buehring \\ Mississippi State University \\ Christine Coker \\ Mississippi State University
}

See next page for additional authors

Follow this and additional works at: https://digitalcommons.unl.edu/usdaarsfacpub

Part of the Agricultural Science Commons

Zheljazkov, Valtcho D.; Vick, Brady A.; Baldwin, Brian S.; Buehring, Normie; Coker, Christine; Astatkie, Tess; and Johnson, Billy, "Oil productivity and composition of sunflower as a function of hybrid and planting date" (2011). Publications from USDA-ARS / UNL Faculty. 889.

https://digitalcommons.unl.edu/usdaarsfacpub/889

This Article is brought to you for free and open access by the U.S. Department of Agriculture: Agricultural Research Service, Lincoln, Nebraska at DigitalCommons@University of Nebraska - Lincoln. It has been accepted for inclusion in Publications from USDA-ARS / UNL Faculty by an authorized administrator of DigitalCommons@University of Nebraska - Lincoln. 
Authors

Valtcho D. Zheljazkov, Brady A. Vick, Brian S. Baldwin, Normie Buehring, Christine Coker, Tess Astatkie, and Billy Johnson 


\title{
Oil productivity and composition of sunflower as a function of hybrid and planting date
}

\author{
Valtcho D. Zheljazkov a,*, Brady A. Vick ${ }^{\mathrm{b}}$, Brian S. Baldwin ${ }^{\mathrm{c}}$, Normie Buehringa ${ }^{\mathrm{a}}$, Christine Coker ${ }^{\mathrm{d}}$, \\ Tess Astatkie ${ }^{\mathrm{e}}$, Billy Johnson ${ }^{\mathrm{f}}$ \\ a Mississippi State University, North Mississippi Research and Extension Center, 5421 Highway 145 South, Verona, MS 38879, USA \\ b Sunflower Research Unit, USDA-ARS, Northern Crop Science Laboratory, 1605 Albrecht Blvd N, Fargo, ND 58102, USA \\ ${ }^{c}$ Mississippi State University, Department of Plant and Soil Sciences, Mississippi State, MS 39762, USA \\ d Mississippi State University, Coastal Research and Extension Center, 1815 Popp's Ferry Road, Biloxi, MS 39532, USA \\ e Dep. of Engineering, Nova Scotia Agricultural College, 50 Pictou Road, P.O. Box 550, Truro NS B2N 5E3, Canada \\ ${ }^{\mathrm{f}}$ Coastal Plain Experiment Station, 51 Coastal Plain Road, Newton, MS 39345, USA
}

\section{A R T I C L E I N F O}

\section{Article history:}

Received 2 July 2010

Received in revised form 5 November 2010

Accepted 10 November 2010

Available online 10 December 2010

\section{Keywords:}

Fatty acid composition

Oil content

Oleic acid

Total saturated fatty acids

Oil yield

Biodiesel

\begin{abstract}
A B S T R A C T
Sunflower (Helianthus annuus L.) is a potential cash crop for the southeastern United States for production of cooking oil or biodiesel. Two years (2006 and 2007) of experiments were conducted at each of five locations in Mississippi to evaluate the effect of planting date (April 20, May 20, and June 20), and hybrid (DKF3875, DKF2990, DKF3510, DKF3901, PR63M80, PR62A91, PR63A21, PR63M91, and PR64H41) on seed yield, oil content, and oil composition of sunflower. Seed oil concentration varied from 25 to $47 \%$. The oleic acid concentration in the oil was greater than 85\% for DKF3510 and PR64H41, above 65\% for PR63M80 and PR63M91, and intermediate for the other hybrids. Total saturated fatty acids (TSFA) concentration in the oil (the sum of palmitic, stearic, arachidic, behenic, and lignoceric acids) ranged from 6.3 to $13.0 \%$, with DKF3510, PR63M91, and PR64H41 having lower concentration of TSFA than the other hybrids. Mean seed yields ranged from 997 to $2096 \mathrm{~kg} \mathrm{ha}^{-1}$ depending on location. Mean oil yields at the five locations ranged from 380 to $687 \mathrm{~kg} \mathrm{ha}^{-1}$, and calculated biodiesel production ranged from 304 to $550 \mathrm{~kg} \mathrm{ha}^{-1}$. Seed and oil yields in this study suggest sunflower in Mississippi should be planted by the last week of May. Later planting (20 June) may significantly decrease both seed and oil yields in the non-irrigated system in Mississippi and in other areas of the southeastern United States with similar environmental conditions.
\end{abstract}

(C) 2010 Elsevier B.V. All rights reserved.

\section{Introduction}

Sunflower (Helianthus annuus L.) is not commonly grown in the southeastern United States, although previous research has shown feasibility of growing sunflower as a cash crop for the region (Zheljazkov et al., 2008). Currently, North American sunflower production is concentrated in North Dakota, South Dakota, Colorado, Kansas, Minnesota, Nebraska, and Texas (Johnston et al., 2002; National Agricultural Statistics Service, 2006) and in Canada (Angadi and Entz, 2002a,b; Johnston et al., 2002). Sunflower is usually grown in rainfed systems because it is relatively drought tolerant (Robinson, 1978; Lindstrom et al., 1982; Stone et al., 2002) and utilizes soil nutrients efficiently (Connor and Hall, 1997; Valchovski, 2002) due to its well-developed and deeply penetrat-

Abbreviations: FA, fatty acid; TSFA, total saturated fatty acids.

* Corresponding author. Tel.: +1 662566 2201; fax: +1 6625662257.

E-mail address: vj40@pss.msstate.edu (V.D. Zheljazkov). ing root system (Jaafar et al., 1993; Nielsen, 1998; Angadi and Entz, 2002a,b; Stone et al., 2002).

Sunflower oil is one of the world's major vegetable oils; it is used in the food industry and in various commercial products, and it has been shown to have significant potential for biodiesel production (Arkansas Bio-Fuels Enterprises, 2007; National Sunflower Association, 2009). Previous research has demonstrated that the fatty acid (FA) composition of sunflower oil depends on genetic and environmental conditions (Robertson et al., 1978; Lajara et al., 1990; Miller and Vick, 1999; Sobrino et al., 2003). In general, the FA profile of vegetable oils determines their nutritional properties and specific uses (Warner et al., 2003; Burton et al., 2004). Usually, sunflower oil comprises up to $90 \%$ unsaturated FAs (combined oleic and linoleic) and approximately $10 \%$ saturated FAs (palmitic and stearic) (Steer and Seiler, 1990). Sunflower hybrids can be divided into three major groups: (i) traditional sunflower with oleic acid content of $14-39 \%$ of the oil; (ii) mid-oleic acid sunflower (42-72\% oleic acid content, also called NuSun in the United States); and (iii) high-oleic acid sunflower (75-91\% oleic acid) (Codex Alimentarius 
Committee, 2005). Sunflower oils with high oleic acid content are considered healthy (Jing et al., 1997; Krajcovicova-Kudlackova et al., 1997), and they have high stability during frying and extended shelf life, which makes them preferable for the 3 billion kgyear ${ }^{-1}$ frying oil market in the United States (Warner et al., 2003). Sunflower breeders have responded to the market demand and have recently developed several hybrids with high oleic acid content (Hardin, 1998; Kleingartner, 2002; Burton et al., 2004).

Sunflower can also be grown for biodiesel production (National Sunflower Association, 2009). The USDA has stated that biodiesel offers environmental, economic, and national security benefits (Kurki et al., 2007). For the period from 1999 to 2006, biodiesel demand in the United States increased over 400 times (National Sunflower Association, 2009). Hence, farmers in the southeastern United States have been interested in sunflower as a potential biodiesel crop. Sunflower was evaluated in the 1970s and 1980s in Florida for biodiesel production (Green et al., 1980, 1981, 1982). Overall, Green et al. (1981) found the open-pollinated Russian varieties Peredovik 66 and Sputnik 71 to provide the highest yields among the varieties they tested; however, a number of new sunflower hybrids have been developed since then to meet specific market requirements for fatty acid composition. Recent research in Mississippi demonstrated the potential for sunflower to be grown as a cash crop for production of vegetable oil or biodiesel (Zheljazkov et al., 2008).

With the advent of new sunflower hybrids with different FA composition, growth characteristics, and vegetation period, there is a need to evaluate their potential productivity, oil content, and FA profile when grown at different latitudes in the southeastern US. The objective was to evaluate the effect of hybrid, and planting date as well as their interaction on yield, oil content, and oil composition of sunflower in five locations in Mississippi, representing four different latitudes.

\section{Materials and methods}

\subsection{Field experiments}

A split-plot design field experiment was conducted during the 2006 and 2007 cropping seasons at five locations in Mississippi: Beaumont, Newton, Starkville, and two locations in Verona, Verona 1 and 2. The factors were (i) planting date (April 20, May 20, and June 20), and (ii) hybrid (DKF3875, DKF2990, DKF3510, DKF3901, PR63M80, PR62A91, PR63M91, PR63A21, and PR64H41). Certified seed for the nine sunflower hybrids was provided by Monsanto Co. (St. Louis, MO) and Pioneer (Pioneer Hi-Bred International Inc., Woodland, CA).

The five locations for the experiment were chosen to represent major growing areas from south to north Mississippi, four different latitudes (Fig. 1), and different soil types (U.S. Department of Agriculture, 2001). The soils at the five locations were McLaurin sandy loam (Beaumont), Prentiss fine sandy loam (Newton), Marietta fine sandy loam (Starkville), Catalpa silty clay loam (Verona 1 ), and Quitman sandy loam (Verona 2). The soil at the five locations was tilled and prepared following the procedure for row crops soil preparation in the region. Land preparation included disking and formation of raised beds at $97-102 \mathrm{~cm}$ center to center at the beginning of April. The herbicide Treflan [trifluralin, 2,6-dinitro$\mathrm{N}, \mathrm{N}$-dipropyl-4-(trifluoromethyl)benzenamine] at $4.5-5.6 \mathrm{~kg} \mathrm{ha}^{-1}$ (preplant incorporated, right after the formation of raised beds) was applied to improve weed control at the five locations. Individual experimental plots were 6 by $4 \mathrm{~m}$, with four rows in every plot. Sunflower planting at the five locations was done using a cone planter at $3.8 \mathrm{~cm}$ depth, at $97-102 \mathrm{~cm}$ interrow space, and a seeding rate that provided 6.4 seed $\mathrm{m}^{-1}$ of row.

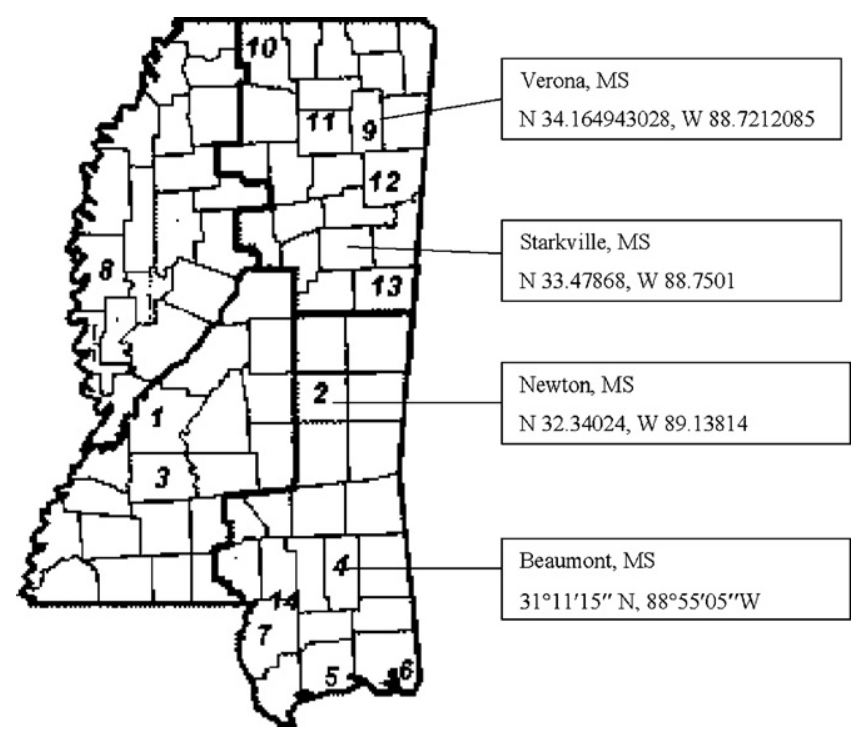

Fig. 1. Map of Mississippi with indication of the counties and the Mississippi Agriculture and Forestry Experiment Stations (MAFES) (1-14). The field experiments with the nine sunflower hybrids were conducted at the MAFES research stations in Beaumont (4), Newton (2), Starkville, and Verona 1 and Verona 2 (9).

During the two growing seasons, several pests were identified. The major pest was blackbirds (red-winged blackbirds, Agelaius phoeniceus L.; common grackles, Quiscalus quiscula L. and some other blackbird species), which were controlled using propane cannons. Other pests included stem weevil (Cylindrocopturus adspersus LeConte) and head clipping weevil (Haplorhynchites aeneus Boh.), which were found at the two Verona locations only and controlled with a single application of Sevin ( $80 \%$ carbaryl [1-naphthalenyl methylcarbamate]) at $1.4 \mathrm{~kg} \mathrm{ha}^{-1}$. Head rot (caused by Rhizopus sp.) incidence was low and did not require control.

Harvesting was done when all plants in a given treatment reached harvesting maturity, after physiological stage R-9 (Schneiter and Miller, 1981), by harvesting the two inner rows in each plot. Sunflower seeds were threshed on a stationary thresher (Almaco, LPR-E, Nevada, IA), and seed moisture was determined by a stationary electronic grain-moisture tester (Model GAC2000, Dickey-John, Auburn, IL) using a 500-g sample from each plot. Sunflower seed subsamples (around $100 \mathrm{~g}$ from each plot) were further cleaned by hand to remove any broken seed or impurities, placed overnight in a freezer at $-20^{\circ} \mathrm{C}$ to prevent disease development and eliminate living insects, and then stored in a refrigerator at $4{ }^{\circ} \mathrm{C}$ to await further analysis.

\subsection{Soil nutrient analyses}

Representative soil samples were taken from the five experimental sites prior to planting, air-dried at room temperature, ground to pass through a $1-\mathrm{mm}$ sieve, and extracted using the Lancaster soil test method (Cox, 2001) at the Mississippi State University Soil Testing and Plant Analyses Laboratory. The nutrient concentration of soil samples was determined by an inductively coupled argon plasma spectrometer (Thermo Jarrell Ash, Franklin, MA). Phosphorus ( $\mathrm{P}$ ) and potassium (K) fertilizers were broadcasted and incorporated following the soil analyses and recommendations at each location. One half of the nitrogen $(\mathrm{N})$ fertilizer was applied prior to planting and the second half as side dressing at the $\mathrm{V}$ 4 growth stage (Schneiter and Miller, 1981) to provide a total of $134 \mathrm{~kg} \mathrm{~N} \mathrm{ha}^{-1}$ over the growing season. Added fertilizer was based on literature data and recent research on sunflower in the region (Zheljazkov et al., 2008, 2009). The fertility blanket was designed 
Table 1

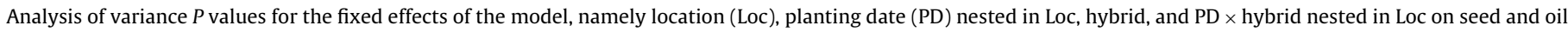
yield, oleic acid, oil content, total saturated fatty acid (TSFA) and linoleic (polyunsaturated fatty acid; PUFA) in Mississippi.

\begin{tabular}{|c|c|c|c|c|c|c|}
\hline Source of variation & Seed yield & Oil yield & Oleic acid & Oil content & TSFA & PUFA \\
\hline Loc & $\underline{0.001}^{\mathrm{a}}$ & $\underline{0.001}$ & $\underline{0.001}$ & $\underline{0.001}$ & $\underline{0.001}$ & $\underline{0.001}$ \\
\hline PD(Loc) & $\overline{0.001}$ & $\overline{0.001}$ & $\overline{0.007}$ & $\overline{0.001}$ & $\overline{0.001}$ & $\overline{0.001}$ \\
\hline Hybrid & 0.001 & 0.001 & 0.001 & $\overline{0.001}$ & 0.001 & 0.001 \\
\hline PD $\times$ hybrid(Loc) & $\underline{0.001}$ & $\underline{0.065}$ & $\underline{0.001}$ & $\overline{0.140}$ & $\underline{0.001}$ & $\underline{0.001}$ \\
\hline
\end{tabular}

a Significant effects that need multiple means comparison are underlined.

to provide understanding of sunflower yield response to planting date, and hybrid, without confounding effects due to limited N, P, or $\mathrm{K}$.

\subsection{Analysis of sunflower FA composition and seed oil content}

The sunflower subsamples from every plot were extracted and analyzed for FA composition on a Hewlett-Packard Model 5890 gas chromatograph as described previously (Zheljazkov et al., 2008). Seed oil content was determined from a $40-\mathrm{mL}$ sample of cleaned, weighed seed from each plot using a Maran Ultra Resonance NMR instrument (Resonance Instruments Ltd., Witney, UK), following the American Oil Chemists' Society Official Methods and Recommended Practices, AK4-95 (American Oil Chemists' Society, 1994) and as described previously (Zheljazkov et al., 2008). Because seed from different hybrids had various moisture contents, oil contents were adjusted to 0 and to $10 \%$ moisture content. We report the oil content based on $0 \%$ moisture content.

\subsection{Statistical methods}

In 2006 and 2007, within each of the five locations (Beaumont, Newton, Starkville, Verona 1, and Verona 2), the experimental field had blocks, and each block was partitioned into three and randomly assigned to the three planting dates (1,2, and 3), and within each planting date the nine hybrids (DKF2990, DKF3510, DKF3875, DKF3901, PR62A91, PR63A21, PR63M80, PR63M91 and PR64H41) were completely randomized. For each location, this layout makes the design split-plot design with planting dates (PD) as the wholeplot treatments and the hybrids as the sub-plot treatments. The two factors of interest (PD, and hybrid) were considered as fixed, and block (with combination of the two years and the four blocks giving a total of eight blocks) was considered as random. In order to compare the five locations, one complete ANOVA was done for each of the two yield and four fatty acid composition responses. Since the PDs used at the five locations were not exactly the same, but similar; and since the 9 hybrids tested at each location were exactly the same, the main effect of location was added on the split-plot design model and the effects of PD and $\mathrm{PD} \times$ hybrid were nested within location. The ANOVA was completed using the Mixed Procedure of SAS (SAS Institute Inc., 2003), and further multiple means comparison was completed for significant $(P<0.05)$ and marginally significant $(0.05<P<0.1)$ effects by comparing the least squares means of the corresponding treatment combinations using the lsmeans statement of Proc Mixed. Letter groupings were gener- ated using a $1 \%$ level of significance when the two-factor interaction effect was significant, and using a $5 \%$ level of significance when a main effect was significant. For each response, the validity of model assumptions was verified by examining the residuals as described in Montgomery (2009).

\section{Results and discussion}

\subsection{Main and interaction effects of planting date and hybrid on measured responses}

Location had a significant effect on seed yield, oil yield, oleic acid concentration, oil content, and on TSFA and PUFA (poly unsaturated fatty acids, in this case it is linoleic acid) (Table 1). Planting date nested within location and hybrid had significant effects on oil content, whereas the planting date by hybrid interaction nested within location had significant effect on the five responses but not on oil content (Table 1 ).

\subsection{Seed and oil yields, oleic acid concentration, oil content, TSFA, and PUFA in different locations}

Overall, mean seed yields at the five locations ranged from 997 to $2096 \mathrm{~kg} \mathrm{ha}^{-1}$ and were as follows: Beaumont $>$ Verona $1>$ Verona $2>$ Newton $>$ Starkville (Table 2). Mean oil yields ranged from 380 to $687 \mathrm{~kg} \mathrm{ha}^{-1}$, with mean yields in Beaumont and Verona 1 being the highest, oil yields at Verona 2 were lower, and oil yields in Newton and Starkville were the lowest. Mean oleic acid concentration was within the 56-65\% range, with the highest mean concentration obtained in Starkville and the lowest in Newton. The mean oil content was 38-42.6\%; the oil content was higher in Starkville and Verona 1, and lower in the other three locations. The mean TSFA was 9.1-9.9\%; TSFA was higher in Newton, lower in Beaumont and Verona 2, and lowest in Verona 1. The mean PUFA(linoleic acid) concentration was $24-33 \%$, and the highest was in Newton, the lowest in Starkville, and intermediate in the other locations (Table 2).

Seed yields within the five locations and depending on the treatments ranged between 217 and $2889 \mathrm{~kg} \mathrm{ha}^{-1}$ (Table 3). Our yields were consistent with a previous study using four hybrids in Mississippi (Zheljazkov et al., 2008). In most instances, average yields from the first and second planting dates were within the range of sunflower hybrids in various locations across the United States (National Sunflower Association, 2009). Overall, seed yields in Newton, Verona 1, and Verona 2 were higher from the first and

Table 2

Mean seed yield, oil yield, oleic acid, oil content and TSFA at the five locations in Mississippi.

\begin{tabular}{|c|c|c|c|c|c|c|}
\hline Location & Seed yield $\left(\mathrm{kg} \mathrm{ha}^{-1}\right)$ & Oil yield ( $\mathrm{kg} \mathrm{ha}^{-1}$ ) & Oleic acid (\%) & Oil content (\%) & TSFA (\%) & PUFA (\%) \\
\hline Beaumont & $2096 a^{a}$ & $687 \mathrm{a}$ & $59.0 \mathrm{~b}$ & $38.0 \mathrm{~b}$ & $9.47 \mathrm{~b}$ & $29.2 \mathrm{~b}$ \\
\hline Newton & $1186 \mathrm{~d}$ & $389 \mathrm{c}$ & $56.0 \mathrm{c}$ & $38.2 \mathrm{~b}$ & $9.88 \mathrm{a}$ & $32.6 \mathrm{a}$ \\
\hline Starkville & 997 e & $380 \mathrm{c}$ & $65.0 \mathrm{a}$ & $42.6 \mathrm{a}$ & $9.35 \mathrm{bc}$ & $24.4 \mathrm{c}$ \\
\hline Verona 1 & $1859 \mathrm{~b}$ & $685 a$ & $59.8 \mathrm{~b}$ & $42.0 \mathrm{a}$ & $9.12 \mathrm{c}$ & $29.4 \mathrm{~b}$ \\
\hline Verona 2 & $1430 \mathrm{c}$ & $512 \mathrm{~b}$ & $59.4 \mathrm{~b}$ & $39.4 \mathrm{~b}$ & $9.56 \mathrm{~b}$ & $29.5 \mathrm{~b}$ \\
\hline
\end{tabular}

a Means followed by the same letter are not significantly different. All pairwise differences were tested using the pdiff option of the lsmeans statement of Proc Mixed. 
Table 3

Mean seed yield from the different combinations of planting dates (PD) and hybrid at the five locations in Mississippi.

\begin{tabular}{|c|c|c|c|c|c|c|}
\hline PD & Hybrid & Beaumont (kg ha $\left.{ }^{-1}\right)$ & Newton $\left(\mathrm{kg} \mathrm{ha}^{-1}\right)$ & Starkville $\left(\mathrm{kg} \mathrm{ha}^{-1}\right)$ & Verona $1\left(\mathrm{~kg} \mathrm{ha}^{-1}\right)$ & Verona $2\left(\mathrm{~kg} \mathrm{ha}^{-1}\right)$ \\
\hline 1 & DKF2990 & 2509 abc & $1491 \mathrm{a}-\mathrm{d}$ & $528 \mathrm{e}$ & 2000 def & 2066 abc \\
\hline 1 & DKF3510 & $2373 a-d^{a}$ & $1651 \mathrm{abc}$ & 713 cde & $2815 \mathrm{ab}$ & $2369 \mathrm{ab}$ \\
\hline 1 & DKF3875 & 1924 de & $1606 a b c$ & 885 b-e & 2503 a-e & $1956 \mathrm{a}-\mathrm{d}$ \\
\hline 1 & DKF3901 & 1903 de & $1532 a b c$ & $1260 \mathrm{abc}$ & $2191 \mathrm{c}-\mathrm{f}$ & 1847 b-e \\
\hline 1 & PR62A91 & $1542 \mathrm{efg}$ & $1258 \mathrm{~b}-\mathrm{e}$ & 605 de & $2281 \mathrm{~b}-\mathrm{e}$ & 1799 cde \\
\hline 1 & PR63A21 & $1148 \mathrm{~g}$ & 781 efg & $1074 \mathrm{a}-\mathrm{d}$ & 1028 hi & 820 hij \\
\hline 1 & PR63M80 & $2420 \mathrm{a}-\mathrm{d}$ & $1848 \mathrm{a}$ & $1151 \mathrm{a}-\mathrm{d}$ & 2889 a & $2473 \mathrm{a}$ \\
\hline 1 & PR63M91 & $2101 \mathrm{~b}-\mathrm{e}$ & $1788 \mathrm{ab}$ & 913 b-e & $2743 \mathrm{ab}$ & $1605 \mathrm{c}-\mathrm{f}$ \\
\hline 1 & PR64H41 & $2506 a b c$ & $1593 a b c$ & $1105 \mathrm{a}-\mathrm{d}$ & $2558 \mathrm{a}-\mathrm{d}$ & $2379 a b$ \\
\hline 2 & DKF2990 & & 1166 cde & $1097 \mathrm{a}-\mathrm{d}$ & $2154 \mathrm{c}-\mathrm{f}$ & $1440 \mathrm{~d}-\mathrm{g}$ \\
\hline 2 & DKF3510 & & $1833 \mathrm{a}$ & $1592 \mathrm{a}$ & 2494 a-e & $1454 \mathrm{~d}-\mathrm{g}$ \\
\hline 2 & DKF3875 & & $1618 a b c$ & $1105 \mathrm{a}-\mathrm{d}$ & 2283 b-e & $1340 \mathrm{e}-\mathrm{h}$ \\
\hline 2 & DKF3901 & & 1626 abc & $1140 \mathrm{a}-\mathrm{d}$ & 2101 def & $1445 \mathrm{~d}-\mathrm{g}$ \\
\hline 2 & PR62A91 & & 990 def & 680 de & 1974 ef & $1574 \mathrm{c}-\mathrm{f}$ \\
\hline 2 & PR63A21 & & 812 ef & 540 e & $1709 \mathrm{fg}$ & $1127 \mathrm{f}-\mathrm{i}$ \\
\hline 2 & PR63M80 & & 1669 abc & $1440 \mathrm{a}$ & $2663 a b c$ & $1581 \mathrm{c}-\mathrm{f}$ \\
\hline 2 & PR63M91 & & $1613 a b c$ & 779 cde & 2463 a-e & 1738 cde \\
\hline 2 & PR64H41 & & $1950 \mathrm{a}$ & $1343 a b$ & $2742 \mathrm{ab}$ & $1695 \mathrm{cde}$ \\
\hline 3 & DKF2990 & 2045 b-e & $578 \mathrm{fg}$ & & $923 \mathrm{hi}$ & $510 \mathrm{j}$ \\
\hline 3 & DKF3510 & 2071 b-e & $687 \mathrm{efg}$ & & $1106 \mathrm{hi}$ & $998 \mathrm{~g}-\mathrm{j}$ \\
\hline 3 & DKF3875 & $2579 \mathrm{ab}$ & $455 \mathrm{fg}$ & & 819 hij & 826 hij \\
\hline 3 & DKF3901 & $2511 \mathrm{abc}$ & 675 efg & & 1147 ghi & $920 \mathrm{~g}-\mathrm{j}$ \\
\hline 3 & PR62A91 & 1716 ef & $217 \mathrm{~g}$ & & $704 \mathrm{ij}$ & 849 hij \\
\hline 3 & PR63A21 & $1229 \mathrm{fg}$ & $251 \mathrm{~g}$ & & $334 \mathrm{j}$ & $624 \mathrm{ij}$ \\
\hline 3 & PR63M80 & $2777 \mathrm{a}$ & $679 \mathrm{efg}$ & & $1286 \mathrm{gh}$ & $1034 \mathrm{~g}-\mathrm{j}$ \\
\hline 3 & PR63M91 & 1980 cde & 771 efg & & $1277 \mathrm{gh}$ & $1128 \mathrm{f}-\mathrm{i}$ \\
\hline 3 & PR64H41 & 2396 a-d & 871 ef & & $1004 \mathrm{hi}$ & $1023 \mathrm{~g}-\mathrm{j}$ \\
\hline
\end{tabular}

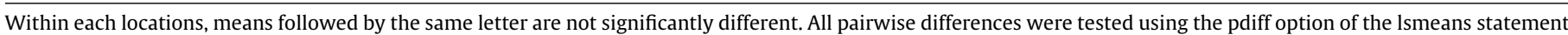
of Proc Mixed.

a a-d represents abcd.

second planting dates and lower from the third (Table 3). However, seed yields in Beaumont from the first and third planting dates were quite similar, whereas the second planting date at this location was unsuccessful due to poor emergence caused by drought. Overall, seed yields in Starkville were lower than in the other locations, and planting date 3 was not successful in that location due to drought (Table 3 ). These results are consistent with general understanding that early planting of sunflower may produce higher yields (Baros et al., 2004; Flagella et al., 2002; Soriano et al., 2004).

Table 4

Mean oil yield from the different combinations of planting dates (PD) and hybrid at the five locations in Mississippi.

\begin{tabular}{|c|c|c|c|c|c|c|}
\hline PD & Hybrid & Beaumont $\left(\mathrm{kg} \mathrm{ha}^{-1}\right)$ & Newton (kg ha $\left.{ }^{-1}\right)$ & Starkville $\left(\mathrm{kg} \mathrm{ha}^{-1}\right)$ & Verona $1\left(\mathrm{~kg} \mathrm{ha}^{-1}\right)$ & Verona $2\left(\mathrm{~kg} \mathrm{ha}^{-1}\right)$ \\
\hline 1 & DKF2990 & $906 \mathrm{ab}$ & $584 \mathrm{abc}$ & 229 ef & 879 b-f & 898 abc \\
\hline 1 & DKF3510 & $731 \mathrm{abc}$ & $677 \mathrm{ab}$ & 302 def & $1154 \mathrm{abc}$ & $976 \mathrm{ab}$ \\
\hline 1 & DKF3875 & $669 \mathrm{bcd}$ & 585 abc & $353 c-f$ & 1003 a-e & $809 a-d$ \\
\hline 1 & DKF3901 & 502 cde & $626 a b$ & $712 \mathrm{a}$ & 946 b-f & $838 \mathrm{a}-\mathrm{d}$ \\
\hline 1 & PR62A91 & 470 cde & $428 b-e^{a}$ & 224 ef & $951 \mathrm{~b}-\mathrm{f}$ & 669 b-e \\
\hline 1 & PR63A21 & 417 de & 252 efg & 231 ef & 405 hij & 309 h-m \\
\hline 1 & PR63M80 & $837 \mathrm{ab}$ & $699 a b$ & $415 \mathrm{~b}-\mathrm{e}$ & $1389 a$ & $1110 \mathrm{a}$ \\
\hline 1 & PR63M91 & 724 abc & $741 \mathrm{a}$ & 396 b-f & $1242 \mathrm{ab}$ & $697 \mathrm{~b}-\mathrm{e}$ \\
\hline 1 & PR64H41 & $840 \mathrm{ab}$ & $656 \mathrm{ab}$ & 396 b-f & $1101 \mathrm{a}-\mathrm{d}$ & $1065 \mathrm{a}$ \\
\hline 2 & DKF2990 & & $345 c-f$ & $503 a-d$ & $811 \mathrm{c}-\mathrm{f}$ & $536 \mathrm{~d}-\mathrm{i}$ \\
\hline 2 & DKF3510 & & $625 \mathrm{ab}$ & 566 abc & $915 \mathrm{~b}-\mathrm{f}$ & $485 \mathrm{e}-\mathrm{j}$ \\
\hline 2 & DKF3875 & & $536 \mathrm{a}-\mathrm{d}$ & $367 c-f$ & $820 c-f$ & 424 e-k \\
\hline 2 & DKF3901 & & $583 \mathrm{abc}$ & $474 a-d$ & 720 efg & $559 \mathrm{~d}-\mathrm{h}$ \\
\hline 2 & PR62A91 & & $351 \mathrm{c}-\mathrm{f}$ & 235 ef & $750 \mathrm{~d}-\mathrm{g}$ & $521 \mathrm{~d}-\mathrm{i}$ \\
\hline 2 & PR63A21 & & 306 def & $198 \mathrm{f}$ & $635 \mathrm{fgh}$ & 382 f-l \\
\hline 2 & PR63M80 & & 604 abc & $646 \mathrm{ab}$ & $1101 \mathrm{a}-\mathrm{d}$ & $560 \mathrm{~d}-\mathrm{h}$ \\
\hline 2 & PR63M91 & & $547 \mathrm{a}-\mathrm{d}$ & 301 def & 962 b-f & $625 c-g$ \\
\hline 2 & PR64H41 & & $633 \mathrm{ab}$ & $547 \mathrm{abc}$ & 1039 a-e & $645 b-f$ \\
\hline 3 & DKF2990 & $673 \mathrm{bcd}$ & $177 \mathrm{fgh}$ & & $312 \mathrm{ij}$ & $166 \mathrm{~m}$ \\
\hline 3 & DKF3510 & 705 abc & $203 \mathrm{fgh}$ & & $317 \mathrm{ij}$ & 327 h-m \\
\hline 3 & DKF3875 & $849 a b$ & $127 \mathrm{gh}$ & & $292 \mathrm{ij}$ & $274 \mathrm{j}-\mathrm{m}$ \\
\hline 3 & DKF3901 & $858 a b$ & 226 efg & & 385 hij & $301 \mathrm{i}-\mathrm{m}$ \\
\hline 3 & PR62A91 & 499 cde & $76 \mathrm{~h}$ & & $208 \mathrm{jk}$ & $246 \mathrm{klm}$ \\
\hline 3 & PR63A21 & $331 \mathrm{e}$ & $68 \mathrm{~h}$ & & $93 \mathrm{k}$ & $194 \mathrm{~lm}$ \\
\hline 3 & PR63M80 & $1054 \mathrm{a}$ & $195 \mathrm{fgh}$ & & 487 ghi & 346 h-m \\
\hline 3 & PR63M91 & 724 abc & 292 efg & & 486 ghi & $368 \mathrm{~g}-1$ \\
\hline 3 & PR64H41 & $815 a b$ & 236 efg & & 416 hi & 342 h-m \\
\hline
\end{tabular}

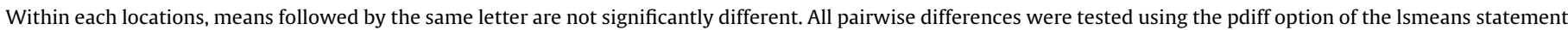
of Proc Mixed.

a b-e represents bcde. 
Table 5

Mean oleic acid concentration from the different combinations of planting dates (PD) and hybrid at the five locations in Mississippi.

\begin{tabular}{|c|c|c|c|c|c|c|}
\hline PD & Hybrid & Beaumont (\%) & Newton (\%) & Starkville (\%) & Verona 1 (\%) & Verona $2(\%)$ \\
\hline 1 & DKF2990 & $53.1 \mathrm{c}$ & $46.5 \mathrm{de}$ & 58.6 cde & $53.7 \mathrm{~d}$ & $55.6 \mathrm{c}$ \\
\hline 1 & DKF3510 & $84.1 \mathrm{a}$ & $87.2 \mathrm{a}$ & 88.7 a & $87.6 \mathrm{a}$ & $87.8 \mathrm{a}$ \\
\hline 1 & DKF3875 & $37.8 \mathrm{f}$ & $39.9 \mathrm{e}-\mathrm{h}^{\mathrm{a}}$ & $49.8 \mathrm{fgh}$ & $44.7 \mathrm{efg}$ & 43.4 def \\
\hline 1 & DKF3901 & 38.7 ef & 45.1 def & $56.4 \mathrm{def}$ & $50.0 \mathrm{de}$ & $47.2 \mathrm{~d}$ \\
\hline 1 & PR62A91 & $36.5 \mathrm{f}$ & 33.8 ghi & $44.2 \mathrm{~h}$ & $41.1 \mathrm{fg}$ & $45.3 \mathrm{de}$ \\
\hline 1 & PR63A21 & $43.8 \mathrm{def}$ & $37.8 \mathrm{f}-\mathrm{i}$ & $62.6 \mathrm{~cd}$ & $46.5 \mathrm{~d}-\mathrm{g}$ & $46.6 \mathrm{~d}$ \\
\hline 1 & PR63M80 & $68.7 \mathrm{~b}$ & 64.9 bc & $71.9 \mathrm{~b}$ & $71.5 \mathrm{~b}$ & $70.3 \mathrm{~b}$ \\
\hline 1 & PR63M91 & $63.0 \mathrm{~b}$ & $60.8 \mathrm{bc}$ & $64.7 \mathrm{bc}$ & $62.5 \mathrm{c}$ & $65.6 \mathrm{~b}$ \\
\hline 1 & PR64H41 & $86.0 \mathrm{a}$ & $88.1 \mathrm{a}$ & $88.0 \mathrm{a}$ & $87.9 \mathrm{a}$ & $88.6 \mathrm{a}$ \\
\hline 2 & DKF2990 & & $48.8 \mathrm{~d}$ & $60.3 \mathrm{~cd}$ & $53.9 \mathrm{~d}$ & $50.3 \mathrm{~cd}$ \\
\hline 2 & DKF3510 & & $86.7 \mathrm{a}$ & $88.3 \mathrm{a}$ & $86.5 \mathrm{a}$ & $86.1 \mathrm{a}$ \\
\hline 2 & DKF3875 & & $41.4 \mathrm{~d}-\mathrm{g}$ & $48.7 \mathrm{gh}$ & $39.7 \mathrm{~g}$ & $37.5 \mathrm{f}$ \\
\hline 2 & DKF3901 & & $47.0 \mathrm{de}$ & 56.8 def & $48.1 \mathrm{def}$ & $47.1 \mathrm{~d}$ \\
\hline 2 & PR62A91 & & $40.9 \mathrm{e}-\mathrm{h}$ & $53.0 \mathrm{efg}$ & $44.5 \mathrm{efg}$ & 45.3 de \\
\hline 2 & PR63A21 & & $47.1 \mathrm{de}$ & $51.7 \mathrm{efg}$ & 48.6 def & $45.7 \mathrm{de}$ \\
\hline 2 & PR63M80 & & $67.5 \mathrm{~b}$ & $71.0 \mathrm{~b}$ & 68.7 bc & $65.3 \mathrm{~b}$ \\
\hline 2 & PR63M91 & & 64.9 bc & $65.2 \mathrm{bc}$ & $62.2 \mathrm{c}$ & $68.2 \mathrm{~b}$ \\
\hline 2 & PR64H41 & & 89.6 a & $90.1 \mathrm{a}$ & $88.3 \mathrm{a}$ & $87.4 \mathrm{a}$ \\
\hline 3 & DKF2990 & $46.7 \mathrm{~cd}$ & 37.1 ghi & & 49.9 de & $47.0 \mathrm{~d}$ \\
\hline 3 & DKF3510 & $88.1 \mathrm{a}$ & $85.6 \mathrm{a}$ & & $86.9 \mathrm{a}$ & $85.5 \mathrm{a}$ \\
\hline 3 & DKF3875 & 43.4 def & $32.4 \mathrm{i}$ & & $42.7 \mathrm{efg}$ & 38.9 ef \\
\hline 3 & DKF3901 & $48.6 \mathrm{~cd}$ & $39.0 \mathrm{f}-\mathrm{i}$ & & 47.5 def & 42.5 def \\
\hline 3 & PR62A91 & $45.6 \mathrm{de}$ & 36.2 ghi & & $42.1 \mathrm{fg}$ & 44.0 def \\
\hline 3 & PR63A21 & $52.7 \mathrm{c}$ & $33.5 \mathrm{hi}$ & & $39.7 \mathrm{~g}$ & $45.2 \mathrm{de}$ \\
\hline 3 & PR63M80 & $70.5 \mathrm{~b}$ & $64.9 \mathrm{bc}$ & & $70.5 \mathrm{~b}$ & 66.2 b \\
\hline 3 & PR63M91 & $66.7 \mathrm{~b}$ & $59.3 \mathrm{c}$ & & $61.6 \mathrm{c}$ & $65.5 \mathrm{~b}$ \\
\hline 3 & PR64H41 & $88.4 \mathrm{a}$ & 86.5 a & & $87.4 \mathrm{a}$ & $86.0 \mathrm{a}$ \\
\hline
\end{tabular}

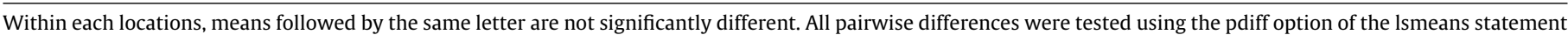
of Proc Mixed.

a $\mathrm{e}-\mathrm{h}$ represents efgh.

\subsection{Oil yields}

Generally, oil yields from the first and second planting dates in Newton, Verona 1, and Verona 2 were greater than oil yields from the third planting date (Table 4). Oil yields from the first and second planting dates at these locations varied from $198 \mathrm{~kg} \mathrm{ha}^{-1}$ (PR63A21 planting date 2 in Starkville) to $1389 \mathrm{~kg} \mathrm{ha}^{-1}$ (PR63M80 planting date 1 in Verona 1). Seed and oil yields in this study suggest sunflower in Mississippi should be planted by the end of May; later planting (20 June) may significantly decrease both seed and oil yields under a non-irrigated system in Mississippi.

\subsection{Oleic acid}

The concentration of oleic acid varied widely among the hybrids and was also affected by location (Table 5). Generally, DKF3510 and PR64H41 have very high oleic acid concentration, in most instances greater than $85 \%$, and are characterized as high oleic acid hybrids (Codex Alimentarius Committee, 2005; National Sunflower Association, 2009). The oleic acid concentration in PR63M80 and PR63M91 (both mid-oleic NuSun hybrids) was greater than 65\%, while the rest of the hybrids had around $45 \%$ concentrations of oleic acid.

\subsection{Seed oil content}

Seed oil content based on $0 \%$ moisture content varied from $25 \%$ (PR63A21 third planting Newton) to 47\% (PR63M80, first planting in Verona 2) (data not shown). Mean seed oil content decreased from the first to the second planting date in Starkville, Verona 1 and Verona 2 locations, but decreased in the third planting date in Newton (Table 6). In Beaumont, the third planting provided higher oil content than the first planting. The seed oil content in different hybrids ranged from 37-38\% (PR62A91, PR63A21, DKF3875) to 41-43\% (PR64H41, DKF2990, PR63M91, PR63M80) (Table 7). Later plantings in Newton and Verona 2 decreased the content of seed oil relative to the first planting. Overall, the seed oil content in this study was comparable to previous reports from Mississippi (Zheljazkov et al., 2008) and from other countries (De la Vega and Hall, 2002; Valchovski, 2002) and was within the range for seed oil concentration of hybrids tested across the United States (National Sunflower Association, 2009). Sunflower producers in the United States may often be paid premiums by oil crusher facilities for seed that is greater than $40 \%$ oil (National Sunflower Association, 2009).

\subsection{Total saturated fatty acids (TSFA)}

Total saturated fatty acid (palmitic, stearic, arachidic, behenic, and lignoceric acids combined) ranged from 6.3\% (PR64H41 third

Table 6

Mean oil content from the different planting dates at the five locations in Mississippi.

\begin{tabular}{|c|c|c|c|c|c|}
\hline Planting date & Beaumont (\%) & Newton (\%) & Starkville (\%) & Verona 1 (\%) & Verona $2(\%)$ \\
\hline 1 & $35.0 \mathrm{de}^{\mathrm{a}}$ & $41.0 \mathrm{bc}$ & $45.7 \mathrm{a}$ & $46.3 \mathrm{a}$ & $43.5 \mathrm{ab}$ \\
\hline 2 & NA & $39.1 \mathrm{bcd}$ & $39.5 \mathrm{bcd}$ & 40.7 bc & 38.5 cde \\
\hline 3 & $41.0 \mathrm{bc}$ & $34.5 \mathrm{e}$ & NA & $38.9 \mathrm{bcd}$ & $36.1 \mathrm{de}$ \\
\hline
\end{tabular}

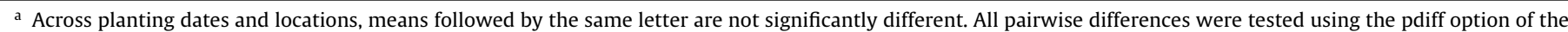
lsmeans statement of Proc Mixed. 
Table 7

Mean oil content from the different hybrids.

\begin{tabular}{ll}
\hline Hybrid & Oil content (\%) \\
\hline DKF2990 & $41.4 \mathrm{ab}^{\mathrm{a}}$ \\
DKF3510 & $39.0 \mathrm{~cd}$ \\
DKF3875 & $38.0 \mathrm{~d}$ \\
DKF3901 & $40.4 \mathrm{bc}$ \\
PR62A91 & $37.3 \mathrm{~d}$ \\
PR63A21 & $37.9 \mathrm{~d}$ \\
PR63M80 & $42.3 \mathrm{a}$ \\
PR63M91 & $42.9 \mathrm{a}$ \\
PR64H41 & $41.2 \mathrm{ab}$ \\
\hline
\end{tabular}

a Means followed by the same letter are not significantly different. All pairwise differences were tested using the pdiff option of the lsmeans statement of Proc Mixed.

planting in Beaumont) to $13.0 \%$ (DKF3901 first planting in Beaumont) (data not shown). This is a wider range for TSFAs than previously reported for four sunflower hybrids (Zheljazkov et al., 2009). Generally, DKF3510, PR63M91, and PR64H41 had lower concentrations of TSFA than the rest of the hybrids.

The mean PUFA (linoleic acid) concentration varied in contrast to the variations in oleic acid concentration; hybrids with high oleic acid and factors increasing oleic acid had correspondingly lower or decreasing concentrations of PUFA (data not shown). Overall, PUFA ranged from $0.8 \%$ (PR64H41 second planting in Starkville) to 50.2\% (PR62A91 first planting in Beaumont); however, DKF3510 and PR64H41 consistently gave below $5 \%$ in all locations and planting dates. The mean concentration of MUFA (the combined concentrations of oleic and gondoic acids) varied the same way as oleic acid (Table 5), because the concentrations of gondoic acid were very small, ranging from 0.13 to $0.34 \%$ ( $\mathrm{Min}=0.13 \mathrm{~m} \mathrm{Q1}=0.19$, mean $=0.225$, Q3 $=0.263$, Max $=0.34 \%$, whereas the values of oleic acid averaged $60 \%$.

\section{Concluding remarks}

This and the previous studies in Mississippi (Zheljazkov et al., 2008) and in other countries (Lajara et al., 1990; Valchovski, 2002) confirm that the FA composition of sunflower oil depends not only on hybrid, but also on environment. Planting dates have a significant influence on sunflower FA composition in Mississippi, which was demonstrated earlier for Texas (Unger, 1980; Jones, 1984). Ultimately, planting dates result in different temperatures during the initial and later stages of sunflower development, and temperature has been shown to be a major modifier of sunflower FA composition (Fernandez-Moya et al., 2002; Izquierdo et al., 2006; Sobrino et al., 2003). Previous research demonstrated that sunflower grown in southern locations may have higher accumulation of oleic acid (Robertson et al., 1978; Zheljazkov et al., 2008) compared to more northern latitudes. High oleic acid and low TSFA cooking oils are preferred by consumers due to the proven nutritional and health benefits (Kleingartner, 2002; Krajcovicova-Kudlackova et al., 1997; Hu et al., 2001).

Our results suggest that a second planting date and in some instances a third can provide seed yields, oil content, and FA composition within the range of sunflower hybrids across the United States (National Sunflower Association, 2009). While the results suggest that an earlier planting date may result in better crop establishment and higher yields, later planting has the advantage of having sunflower as a second crop, perhaps after winter crops such as winter mustard (B. cretica Lam.). Our preliminary trials showed winter mustard reaches technical maturity and can be harvested beginning in June (Zheljazkov et al., submitted for publication), at a time between the second and third planting dates in this study. This opens the possibility for double cropping of winter canola or winter mustard and sunflower in Mississippi and possibly in other states of the southeastern United States. Double cropping of oilseed crops would increase the economic and environmental sustainability of crop production in the southeastern United States. Also, double cropping of winter canola or mustard with sunflower may produce up to four times higher biodiesel yield per area compared with soybean [Glycine max (L.) Merr.].

\section{Acknowledgements}

Authors acknowledge the financial support of the Department of Energy for the project Feedstock for Sustainable Energy Systems in Mississippi. Authors thank Mr. Thomas Horgan, Mrs. Scott Horton, Mr. Robert Dobbs, Mr. Mike Ely for their help in the field and laboratory. Approved for publication as Journal Article No. J-11846 of the Mississippi Agricultural and Forestry Experiment Station, Mississippi State University.

\section{References}

American Oil Chemists' Society, 1994. Official Methods and Recommended Practices of American Oil Chemists' Society, 4th ed. Am. Oil Chem. Soc. Press, Champaign, IL.

Angadi, S.V., Entz, M.H., 2002a. Root system and water use patterns of different height sunflower cultivars. Agron. J. 94, 136-145.

Angadi, S.V., Entz, M.H., 2002b. Water relations of standard height and dwarf sunflower cultivars. Crop Sci. 42, 152-159.

Arkansas Bio-Fuels Enterprises, 2007. Crop Yields in Gallons, Available at http://home.earthlink.net/ arkansasbiofuels/id33.html (accessed April 2007; verified 11 May 2010).

Baros, J.F.C., Carvalhoa, M., de Bascha, G., 2004. Response of sunflower (Helianthus annuus L.) to sowing date and plant density under Mediterranean conditions. Eur. J. Agron. 21, 347-356.

Burton, J.W., Miller, J.F., Vick, B.A., Scarth, R., Holbrook, C.C., 2004. Altering fatty acid composition in oil seed crops. Adv. Agron. 84, 273-306.

Codex Alimentarius Committee, 2005. Codex Standard for Named Vegetable Oils. Codex-Stan 210, p. 2 http://www.codexalimentarius.net/download/ standards/336/CXS_210e.pdf (accessed 11 May 2010).

Connor, D.J., Hall, A.J., 1997. Sunflower physiology. In: Schneiter, A.A.(Ed.), Sunflower Technology and Production. ASA, Madison, WI, pp. 113-182, Agron. Series No. 35.

Cox, M.S., 2001. The Lancaster soil test method as an alternative to the Mehlich 3 soil test method. Soil Sci. 166, 484-489.

De la Vega, A.J., Hall, A.J., 2002. Effect of planting date, genotype, and their interactions on sunflower yield. II. Components of oil yield. Crop Sci. 42, 1202-1210.

Fernandez-Moya, V., Martinez-Force, E., Garces, R., 2002. Temperature effect on high-stearic acid sunflower mutant. Phytochemistry 59, 33-37.

Flagella, Z., Rotunno, T., Tarantino, E., Di Caterina, R., De Caro, A., 2002. Changes in seed yield and oil fatty acid composition of high oleic sunflower (Helianthus annuus $\mathrm{L}$.) hybrids in relation to the sowing date and the water regime. Eur. J. Agron. 17, 221-230.

Green Jr., V.E., Roath, W.W., Robertson, J.A., Zimmerman, D.C., Yang, S.M., Genung W.B., 1982. Oilseed Sunflower Research in Florida 1981. Agron. Res. Rep. AG-821. Inst. of Food and Agric. Sci., Univ. of Florida.

Green Jr., V.E., Robertson, J.A., Bailey, B.A., Simone, G.W., Simone, F.A., Johnson, F.A., Genung, W.B., 1980. Oilseed Sunflower Research in Florida 1979. Agron. Res. Rep. AG-80-4. Inst. of Food and Agric. Sci., Univ. of Florida.

Green Jr., V.E., Robertson, J.A., Simone, G.W., Dunn, R.A., Genung, W.B., Yang, S.M., 1981. Oilseed Sunflower Research in Florida 1981. Agron. Res. Rep. AG-81-3. Inst. of Food and Agric. Sci., Univ. of Florida.

Hardin, B., 1998. Mid-oleic acid sunflower hybrids debut. Agric. Res. 46, 14-15.

Hu, F.B., Manson, J.E., Willett, W.C., 2001. Types of dietary fat and risk of coronary heart disease: a critical review. J. Am. Coll. Nutr. 20, 5-19.

Izquierdo, N.G., Aguirrezábal, L.A.N., Andrade, F.H., Cantarero, M.G., 2006. Modeling the response of fatty acid composition to temperature in a traditional sunflower hybrid. Agron. J. 98, 451-461.

Jaafar, M.N., Stone, L.R., Cordrum, D.E., 1993. Rooting depth and dry matter development of sunflower. Agron. J. 85, 281-286.

Jing, M., Folsom, A.R., Lewis, L., Eckfeldt, J.H., Ma,J., 1997. Relation of plasma phospholipid and cholesterol ester fatty acid composition of carotid artery intima-media thickness: The Artherosclerosis Risk in Communities (ARIC) study. Am. J. Clin. Nutr. 65, 551-559.

Johnston, A.M., Tanaka, D.L., Miller, P.R., Brandt, S.A., Nielsen, D.C., Lanfond, G.P. Riveland, N.R., 2002. Oilseed crops for semiarid cropping systems in the northern Great Plains. Agron. J. 94, 231-240.

Jones, O.R., 1984. Yield, water-use efficiency and oil concentration and quality of dryland sunflower grown in the southern High Plains. Agron. J. 76, 229-235.

Kleingartner, L.W., 2002. NuSun sunflower oil: redirection of an industry. In: Janick, J., Whipkey, A.(Eds.), Trends in New Crops and New Uses. ASHS Press, Alexandria, VA, pp. 135-138. 
Krajcovicova-Kudlackova, M., Simoncic, R., Bederova, A., Klvanova, J., 1997. Plasma fatty acid profile and alternative nutrition. Ann. Nutr. Metab. 41, 365-370.

Kurki, A., Hill, A., Morris, M., 2007. Biodiesel: The Sustainability Dimensions. National Sustainable Agriculture Information Service, Butte, MT, Available at http://attra.ncat.org/attra-pub/biodiesel_sustainable.html (accessed June 2009; verified 11 May 2010).

Lajara, J.R., Diaz, U., Quidiello, R.D., 1990. Definite influence of location and climatic conditions on the fatty acid composition of sunflower oil. J. Am. Oil Chem. Soc. 67, 618-623.

Lindstrom, M.J., Warnes, D.D., Evans, S.D., 1982. A water use comparison between corn and sunflowers. J. Soil Water Conserv. 37, 362-364.

Miller, J.F., Vick, B.A., 1999. Inheritance of reduced stearic and palmitic acid content in sunflower seed oil. Crop Sci. 39, 364-367.

Montgomery, D.C., 2009. Design and Analysis of Experiments, 7th ed. Wiley, New York.

National Agricultural Statistics Service, 2006. Acreage. Agricultural Statistics Board, U.S. Department of Agriculture, Available at: http://usda.mannlib.cornell. edu/usda/nass/Acre/2000s/2006/Acre-06-30-2006.pdf (accessed June 2007; verified 11 May 2010).

National Sunflower Association, 2009. http://www.sunflowernsa.com (accessed October 2009; verified 11 May 2010).

Nielsen, D.C., 1998. Comparison of three alternative oilseed crops for the central Great Plains. J. Prod. Agric. 11, 336-341.

Robertson, J.A., Chapman, J.R., Wilson, J.R., 1978. Relation of days after flowering to chemical composition and physiological maturity. J. Am. Oil Chem. Soc. 55, 266-269.

Robinson, R.G., 1978. Production and culture. In: Carter, J.F. (Ed.), Sunflower Science and Technology. Agron. Monogr. 19. ASA, CSSA, and SSSA, Madison, WI, pp. 89-143.

SAS Institute Inc., 2003. SAS OnlineDoc, Version 9.2. SAS Institute Inc., Cary, NC.

Schneiter, A.A., Miller, J.F., 1981. Description of sunflower growth stages. Crop Sci. 21, 901-903.
Sobrino, E., Tarquis, A.M., Diaz, M.C., 2003. Modeling the oleic acid content in sunflower oil. Agron. J. 95, 329-334.

Soriano, M.A., Orgaz, F., Villalobos, F.J., Fereres, E., 2004. Efficiency of water use of early plantings of sunflower. Eur. J. Agron. 21, 465-476.

Steer, B.T., Seiler, G.J., 1990. Changes in fatty acid composition of sunflower (Helianthus annuus) seeds in response to time of nitrogen application, supply rates and defoliation. J. Sci. Food Agric. 51, 11-26.

Stone, L.R., Goodrum, D.E., Schlegel, A.J., Jaafar, M.N., Khan, A.H., 2002. Water depletion depth of grain sorghum and sunflower in the central high plains. Agron. J. 94, 936-943.

Unger, P.W., 1980. Planting date effects on growth, yield, and oil of irrigated sunflower. Agron. J. 72, 914-916.

U.S. Department of Agriculture, 2001. Official Soil Series Descriptions. USDASoil Survey Division, Natural Resources Conservation Service, Available at http://soils.usda.gov/technical/classification/osd/index.html (accessed 7 March 2006; verified 11 May 2010).

Valchovski, I., 2002. Influence of heavy rate of nitrogen fertilizer on oil content and fatty acid composition of different varieties and hybrids. Rasteniev'dni Nauki 39 $(5 / 6), 338-341$.

Warner, K., Vick, B.A., Kleingartner, L., Isaac, I., Doroff, K., 2003. Composition of sunflower NuSun (mid-oleic sunflower), and high-oleic sunflower oils. In: Proc. Sunflower Res. Workshop, Fargo, ND, 16-17 January 2003. National Sunflower Assoc., Mandan, ND, Available at http://www.sunflowernsa.com/research/ research-workshop/documents/107.PDF.

Zheljazkov, V.D., Vick, B.A., Baldwin, B.S., Buehring, N., Astatkie, T., Johnson, B., 2009. Oil content and saturated fatty acids in sunflower as a function of planting date, nitrogen, and hybrid. Agron. J. 101, 1003-1011.

Zheljazkov, V.D., Vick, B.A., Ebelhar, M.W., Buehring, N., Baldwin, B., Astatkie, T., Miller, J.F., 2008. Yield, oil content, and composition of sunflower (Helianthus annuus L.) grown at multiple locations in Mississippi. Agron. J. 100, 635-642.

Zheljazkov, V.D., Vick, B.A., Ebelhar, M.W., Buehring, N., Astatkie, T., submitted for publication. Effect of $\mathrm{N}$ on seed and oil yields and fatty acid composition of winter canola and mustard. Agron. J. 